\section{BMJ Paediatrics Open}

\title{
Cuba: Solidarity, Ebola and COVID-19
}

To cite: Escobedo AA, Auza-Santiváñez C, Rumbaut R, et al. Cuba: Solidarity, Ebola and COVID-19. BMJ Paediatrics Open 2021;5:e001089. doi:10.1136/ bmjpo-2021-001089

Received 12 March 2021 Revised 20 April 2021 Accepted 6 May 2021
Check for updates

(C) Author(s) (or their employer(s)) 2021. Re-use permitted under CC BY-NC. No commercial re-use. See rights and permissions. Published by BMJ.

${ }^{1}$ Department of Epidemiology, Institute of Gastroenterology, Havana, Cuba

${ }^{2}$ Universidad Mayor de San Andrés. Psychopedagogical and Research Center in Higher Education, La Paz, Bolivia ${ }^{3}$ Department of Communicable Diseases, Ministry of Public Health, Havana, Cuba

${ }^{4}$ Department of Public Health, Laboratory for Mother and Child Health, Mario Negri Institute for Pharmacological Research, Milan, Italy

${ }^{5}$ Academic Division of Child Health, University of Nottingham School of Medicine, Derby, UK

Correspondence to Emeritus Professor Imti Choonara; Imti.Choonara@ nottingham.ac.uk
CUBA

Cuba is a small middle-income Caribbean country with excellent public services, notably in education and health. Both health and education are free and universal for all inhabitants. Free education has resulted in Cuba having one of the highest number of medical doctors per head of population (84.8 per $10000) .{ }^{1}$ Despite having a large number of doctors, Cuba is training over 60000 medical students, with 8-10 000 students anticipating graduating each year. ${ }^{1}$ This includes the 8000 overseas students training at the Latin American School of Medicine. ${ }^{1}$ Universal healthcare and an excellent primary healthcare system have ensured that health indices are excellent in Cuba, comparable with high-income countries. ${ }^{2}$ For example, child mortality is lower in Cuba than in the USA. ${ }^{2}$ It is also lower than in all other countries in Latin America and the Caribbean. ${ }^{2}$

The Cuban healthcare system has trained thousands of foreign doctors, offered free services and responded to health crises around the globe, as during the Ebola epidemic or the current COVID-19 pandemic. This editorial describes the Cuban approach to providing healthcare assistance to people in other countries, using the examples of Ebola and COVID-19. Both Ebola and COVID-19 have affected adults more than children. The impact of both Ebola and COVID-19 on health services, however, has significantly affected children. This has been documented for COVID-19, where the disease has affected high-income countries. Children have experienced social isolation, loss of education and play, and vulnerable children are the ones most likely to have long-term problems. ${ }^{3}$

\section{THE VALUE OF SOLIDARITY}

Cubans have always understood the value of solidarity. The USA has imposed an economic blockade on Cuba. In a world of huge inequalities, Cuba has been the victim of the economic blockade by the USA for almost 60 years, with the supposed objective of generating more democratic models of governance. Economic sanctions always adversely affect the human rights of the whole population and are counterproductive. The recognition by the USA, of the failure of this policy, led to the normalisation of relations announced bilaterally on 17 December 2014 by the presidents of the USA and Cuba. ${ }^{4}$ Unfortunately, these measures were unilaterally reversed by the USA several years later. It is to be hoped that the USA will reconsider its unilateral imposition of economic sanctions on countries like Cuba and move to a more constructive engagement.

Due to the economic blockade, Cuba has had to rely on donations of many goods from others. In response, Cuba has always tried to help other countries following natural disasters. After an earthquake in Chile in 1960, Cuba sent doctors to help. ${ }^{5}$ Since then, Cuban health professionals, teachers and engineers have volunteered to work in over 70 different countries. Cuba initially only offered support following natural disasters. Subsequently, they expanded their collaboration to facilitate primary care and also train doctors. ${ }^{6}$ The USA has been putting pressure on other countries to expel Cuban doctors by launching a campaign of 'fake news' (disinformation). The disinformation is exposed in the documentary 'The War on Cuba-Episode $3{ }^{6}{ }^{6}$ The USA has played a major role in disinformation during the COVID-19 pandemic. ${ }^{7}$

An example of Cuba's approach to solidarity is illustrated by South Africa, where Cuba has trained doctors for over 20 years and is currently training 700 South Africans each year. ${ }^{8}$ Other examples of collaboration lasting more than a decade include TimorLeste and the Pacific Islands (Fiji, Kiribati, Nauru, Solomon Islands, Tonga, Tuvalu and Vanuatu). ${ }^{9}$

Initially, Cuba covered all the costs of their health professionals working overseas. ${ }^{6}$ However, as international collaboration increased, it became apparent that some countries could contribute financially. It is 
estimated that there were over 140000 Cuban professionals working in 67 countries between 2011 and 2016. ${ }^{10}$ Over one-third of the countries (30) paid Cuba for their assistance and just under one-third (20) were paid for fully by Cuba. ${ }^{9}$ In the remaining 17 countries, the costs were shared.

Cuba's role in relation to assisting other countries has been recognised by the WHO and its regional office, the Pan American Health Organization (PAHO). It was through PAHO that Cuba responded to Brazil's request for health professionals for the most deprived areas of Brazil. ${ }^{5}$ The name the Henry Reeve International Medical Brigade (HRIMB) was used from 2005 for Cubans responding to emergencies. ${ }^{11}$ Cuba's response to the outbreaks of Ebola and COVID-19 illustrates its attitude towards solidarity between countries and is described in more detail below.

\section{EBOLA}

The first case of Ebola in Guinea was reported in December 2013. ${ }^{12}$ By August 2014, there had been more than 1000 deaths from Ebola in the three West African countries (Guinea, Liberia and Sierra Leone). ${ }^{12}$ The lack of an adequate health infrastructure was one of the main contributory factors to the rapid spread of Ebola. In August, the head of WHO, Dr Margaret Chan, contacted Cuba to see if they could help. ${ }^{13}$ Cuba already had over 4000 health professionals working in 32 different countries in Africa. ${ }^{13}$

Cuba responded by launching an appeal to health professionals to volunteer to work in West Africa. ${ }^{14}$ Over 10000 volunteered, of whom 465 were selected for training at the Pedro Kouri Institute of Tropical Medicine in Havana. ${ }^{14}$ They were trained in the management of Ebola. Some of the doctors would go to Africa, while others would remain in Cuba to treat cases of Ebola that could be imported-or potentially introduced-into the country. The timeline of Cuba's response is shown in table 1 . The offer to send 165 health professionals to Sierra Leone was welcomed by the WHO. ${ }^{15}$ The first brigade arrived in Sierra Leone on 2 October $2014 .{ }^{16}$ The financial agreement between Cuba and the WHO was that
WHO would cover the expenses of the Cubans working in the brigades against Ebola, but that Cuba would not receive any financial payment for their services. ${ }^{14}$

The Cubans stayed for 6 months. The fatality rate in the emergency treatment centres was reduced from $80 \%-90 \%$ to $24 \%$ by providing supportive treatment. ${ }^{14}$ During their stay, two Cuban volunteers died with malaria. ${ }^{12} 14$ One Cuban volunteer developed Ebola, but recovered following treatment in Geneva. ${ }^{12} 14$ Following a recovery period in Cuba, he returned to Sierra Leone to combat Ebola. In 2017, the HRIMB received the Dr Lee Jong-Wook Memorial prize from WHO. ${ }^{17}$

\section{SARS-COV-2/COVID-19}

Cuba has taken extensive measures in fighting the SARS-CoV-2/COVID-19 pandemic on the international frontline. The SARS-CoV-2/COVID-19 pandemic resulted in Italy experiencing a major crisis in healthcare provision. Italy asked Cuba for assistance and the HRIMB arrived in Italy at the end of March. The 52 Cuban doctors and health workers established a field hospital in Crema alongside the city hospital. The Cuban personnel worked there for 60 days, treating approximately 100 patients with COVID-19. The daily cost of the brigade was around $€ 2850$. The work of the Cuban medical brigade was recorded by the Italian photographer Diana Bagnoli. ${ }^{18}$ In mid-April, a second brigade of Cuban health workers (21 doctors, 16 nurses and a logistician) supported the activities of the field hospital set-up in Turin. ${ }^{19}{ }^{20}$ The Italians thanked Cuba in numerous ways including illuminating one of the famous buildings in Turin (figure 1).

Italy is the third largest economy in the European Union and the request to Cuba for medical assistance is unique and reflects both the scale of the COVID-19 pandemic and the expertise of Cuba in sending medical brigades overseas. In total, 53 Cuban medical brigades have helped to cope with the disease in 39 countries and territories, which joined those that were already offering their services in 59 nations. ${ }^{21}$

Despite sending health professionals to 39 countries to combat COVID-19, Cuba has managed to control the pandemic in Cuba itself. The fatality rate in Cuba from

\begin{tabular}{|c|c|c|}
\hline 2014 & Action & Reference \\
\hline 13 August & UN calls for global response & $13 p 45$ \\
\hline 29 August & Letter from president of Sierra Leone requesting help from Cuba & $13 \mathrm{p} 45$ \\
\hline 9 September & $\begin{array}{l}\text { Phone call from UN secretary general to several world leaders requesting help (presidents of } \\
\text { USA, France, EU, Cuba and prime minister of UK) }\end{array}$ & 13 p37-38 \\
\hline 13 September & $\begin{array}{l}\text { Press conference by Cuba's health minister and Dr Chan (WHO) announcing decision to send } 62 \\
\text { doctors and } 103 \text { nurses to Sierra Leone }\end{array}$ & 15 \\
\hline 15 September & Requests for help from presidents of Liberia and Guinea & 13 p48-50 \\
\hline 16 September & Cuba announces it will send 53 health professionals to Liberia and 38 to Guinea & $13 \mathrm{p} 48-50$ \\
\hline 2 October & Cuban brigade arrives in Sierra Leone & 16 \\
\hline
\end{tabular}

EU, European Union; UN, United Nations. 


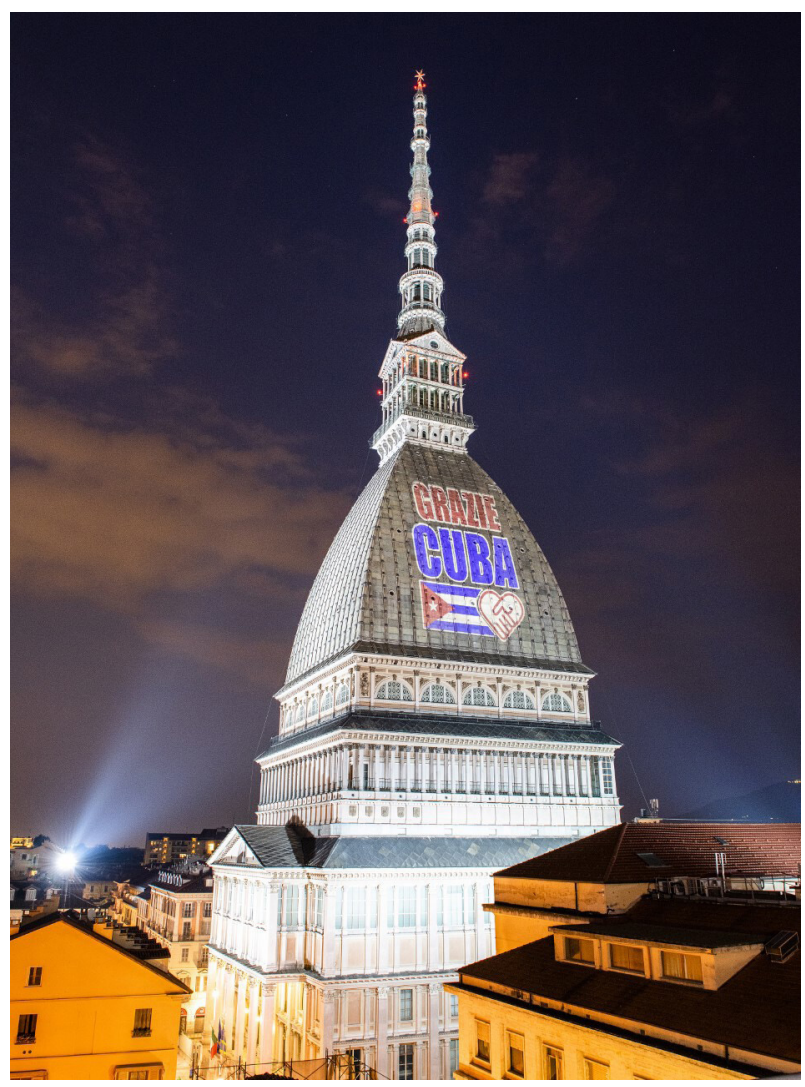

Figure 1 Mole Antonelliana, Turin, Italy. The day after the Cuban brigade departure, the city dedicated a projection on the Mole Antonelliana, the main Torino's symbolic monument, as a sign of thanksgiving for their work. Credits: Diana Bagnoli/National Geographic Society COVID-19 Emergency Fund.

COVID-19 as of 28 February 2021, according to the WHO, was 28 per million people. ${ }^{22}$ In contrast, the fatality rates in Italy and the UK were 1613 and 1808 per million people, respectively. ${ }^{22}$ Cuba's management of COVID-19 has been based on an excellent primary healthcare system and political will to minimise deaths. Government interventions were taken early during the pandemic. Cuba's preceding experience facing epidemics, tackled in the context of a universal health system, was an advantage. Mass surveillance for new cases, involving medical students going from door to door, alongside contact tracing with isolation of cases and contacts, have helped to keep COVID-19 under control in Cuba. ${ }^{23}$ Additionally, the government ensured financial support to families to support the implementation of stay-at-home restrictions.

\section{CUBAN BIOTECHNOLOGY}

A third example of Cuban solidarity is its development of vaccines and medicines. Cuban scientists have established biotechnology and pharmaceutical capacities and capabilities that have made significant contributions to science and public health, especially in vaccines, which are one of the most important medical interventions for reducing morbidity and mortality. The holding company
BioCubaFarma, that produces 8 of the 12 vaccines of the national immunisation programme, is currently studying five potential vaccines against COVID-19:

Soberana 2, a vaccine that contains a part of the coronavirus spike protein, fused to a standard tetanus vaccine; Soberana 1 , a vaccine that contains a part of the spike protein along with proteins from a bacteria and aluminium hydroxide; Soberana Plus, a vaccine protecting against reinfection in convalescent individuals; Abdala (the name is from a poem by the 19th century poet José Marti) is a further viral vector vaccine; Mambisa is a vaccine delivered as a nasal spray that contains a piece of the coronavirus spike protein called along with a protein from the hepatitis B virus that stimulates the immune system. The name refers to women who fought in Cuba's 19th century wars of independence. Cuban vaccines represent $8 \%$ of all vaccines to date in clinical trials. ${ }^{24}$ Vaccines, if proven effective and safe, can also be sent around the world: another way for Cuba to contribute to the right to health for all.

The HRIMB has been nominated by a number of international organisations for the Nobel Peace Prize for its significant contribution to humanity in the global battle against the pandemic caused by SARS-CoV-2/COVID-19.

\section{CONCLUSION}

Cuba is a collaborative partner and an international actor that has shown solidarity to facilitate the global response (principally, and not only) through extending support to others with sharing expertise. The decision to both train and offer health professionals to other countries is consistent with the Cuban political philosophy that health is a human right for all people in the world. Pandemics are a common challenge faced by human beings in an age of globalisation. This has highlighted an important principle: we are all in this together and cooperation is a necessity not a choice. Hence, in relation to the provision of healthcare and solidarity, one can learn a lot from Cuba, a country that time after time globalises solidarity.

Twitter Maurizio Bonati @mumchild_irfmn

Contributors All authors have contributed to the paper and approved the final version.

Funding The authors have not declared a specific grant for this research from any funding agency in the public, commercial or not-for-profit sectors.

Competing interests IC is editor-in-chief, $A A E$ is an assistant editor and $M B$ is on Editorial Advisory Board of BMJ Paeds Open.

Patient and public involvement Patients and/or the public were not involved in the design, or conduct, or reporting, or dissemination plans of this research.

Patient consent for publication Not required.

Provenance and peer review Commissioned; externally peer reviewed.

Open access This is an open access article distributed in accordance with the Creative Commons Attribution Non Commercial (CC BY-NC 4.0) license, which permits others to distribute, remix, adapt, build upon this work non-commercially, and license their derivative works on different terms, provided the original work is properly cited, appropriate credit is given, any changes made indicated, and the use is non-commercial. See: http://creativecommons.org/licenses/by-nc/4.0/. 
ORCID iDs

Angel A Escobedo http://orcid.org/0000-0002-6241-3340

Maurizio Bonati http://orcid.org/0000-0003-3997-3726

Imti Choonara http://orcid.org/0000-0002-3069-6323

\section{REFERENCES}

1 Ministerio de Salud Pública. Anuario estadistico de salud, 2018. Available: https://files.sld.cu/bvscuba/files/2019/04/AnuarioElectronico-Espanol-2018-ed-2019-compressed.pdf [Accessed 10 Apr 2021].

2 Castelló González M, Choonara I. Cuba's success in child health: what can one learn? BMJ Paediatr Open 2019;3:e000573.

3 Crawley E, Loades M, Feder G, et al. Wider collateral damage to children in the UK because of the social distancing measures designed to reduce the impact of COVID-19 in adults. BMJ Paediatr Open 2020;4:e000701.

4 Armstrong F. U.S.-Cuba Normalization:entering a new, challenging phase. Available: https://www.american.edu/centers/latin-americanlatino-studies/upload/reynold-us-cuba-policy-brief-4.pdf [Accessed 10 Apr 2021].

5 Castelló González M, Pons Vásquez R, Rodriguez Bencomo D, et al. International medical collaboration: lessons from Cuba. Children 2016;3. doi:10.3390/children3040020. [Epub ahead of print: 1810 2016].

6 The War on Cuba - Episode3. Available: https://www.youtube.com/ watch?v=_pNBp0n08ak [Accessed 8 Mar 2021].

7 Evanega S, Lynas M, Adams J, et al. Coronavirus misinformation:quantifying sources and themes in the COVID19'infodemic. Available: https://int.nyt.com/data/documenttools/ evanega-et-al-coronavirus-misinformation-submitted-07-23-20-1/ 080839ac0c22bca8/full.pdf [Accessed 10 Apr 2021].

8 Squires N, Colville SE, Chalkidou K, et al. Medical training for universal health coverage: a review of Cuba-South Africa collaboration. Hum Resour Health 2020;18:12.

9 Ferrinho P, Valdes AC, Cabral J. The experience of medical training and expectations regarding future medical practice of medical students in the Cuban-supported medical school in Timor-Leste. Hum Resour Health 2015;13:13.
10 De Vos P. Cuba's strategy toward universal health. Int $J$ Health Serv 2019;49:186-92.

11 Roque YV. XV años de solidaridad. Brigada Henry reeve revista panorama. Cuba y Salud, 2020: 5-6.

12 Chaple EB, Mercer MA. The Cuban response to the Ebola epidemic in West Africa: lessons in solidarity. Int $J$ Health Serv 2017:47:134-49.

13 Gomez EU, Zone R. Cuba and the battle against Ebola in West Africa. Pathfinder Press, 2019: 45-6.

14 Pérez-Avila J, Núñez-Monteagudo D, Muné-Jiménez M, et al. Cuban strategy and medical cooperation to combat Ebola, 2014-2016. MEDICC Rev 2019;21:53-8.

15 Gulland A, Anne G. Cuba pledges 165 health workers to treat Ebola patients in Sierra Leone. BMJ 2014;349:g5647.

16 Ebrahim S, Squires N, Díaz MB, et al. Ebola control: the Cuban approach. Lancet 2014;384:384.

17 PAHO. Cuba's Henry Reeve international medical Brigade receives prestigious Award. Available: https://www.paho.org/hq/index.php? option=com_content\&view=article\&id=13375:cubas-henry-reeveinternational-medical-brigade-receives-prestigious-award [Accessed 14 Dec 2020].

18 Bagnoli D. Diana Bagnoli photography. Available: http://www. dianabagnoli.com/the-cuban-brigade [Accessed 3 Jan 2021].

19 Cuba debate. Available: http://www.cubadebate.cu/noticias/2020/ 07/20/medicos-que-lucharon-contra-la-covid-19-en-turin-ya-estanen-cuba/ [Accessed 16 Dec 2020].

20 Bonati M. Internazionalismo sanitario. Ricerca \& Pratica 2020;37:151-3.

21 Speech at UN. Available: http://en.granma.cu/discursos-raul/202012-03/statement-by-miguel-mario-diaz-canel-bermudez-at-thethirty-first-special-session-of-the-united-nations-general-assembly [Accessed 14 Dec 2020].

22 WHO. Weekly epidemiological update, 2021. Available: https://www. who.int/publications/m/item/weekly-epidemiological-update-2march-2021 [Accessed 8 Mar 2021].

23 Pérez Riverol A. The Cuban strategy for combatting the COVID-19 pandemic. MEDICC Rev 2020;22:64-8.

24 Zimmer C, Corum J, Sui-Lee W. Corona virus vaccine Tracker. New York times. Available: https://www.nytimes.com/interactive/2020/ science/coronavirus-vaccine-tracker.html\#sovereign [Accessed 24 Dec 2020]. 